\title{
CHEMICAL CHANGES IN BEAN GRAINS DURING STORAGE IN CONTROLLED
} CONDITIONS

Doi:http://dx.doi.org/10.1590/1809-4430-Eng.Agric.v37n3p529-540/2017

\section{ANA J. B. DE ALMEIDA ${ }^{1 *}$, SILVIA R. M. COELHO², VANDERLEIA SCHOENINGER ${ }^{3}$, DIVAIR CHRIST ${ }^{2}$ \\ 1* Corresponding author. Western Paraná State University/ Cascavel - PR, Brasil. E-mail: anajulia_ajba@yahoo.com.br}

\begin{abstract}
Bean (Phaseolus vulgaris L.) is a traditional food in the diet of Brazilians, due to its low fat content and it is rich in vitamins, protein, fiber, carbohydrates and minerals. One of the major problems related to this product is storage without temperature and humidity control, causing quality reduction of this legume. This study aimed to evaluate the effects suffered by cooking time parameters, seed coat color, phytate and minerals ( $\mathrm{P}, \mathrm{Ca}, \mathrm{Mg}$ and $\mathrm{Mn}$ ) content during storage. The grain varieties: BRS Madrepérola, BRS Estilo, BRS Pontal and CNFC 10467, from the pinto group, were stored in hermetic acrylic containers with humidity and temperature controlled for a period of 108 days. All varieties had better results of the parameters studied when they were stored under the condition of $15^{\circ} \mathrm{C}$ and $45 \%$ of $\mathrm{RH}$. The grain stored in the condition of $27^{\circ} \mathrm{C}$ and $75 \%$ of humidity for 108 days showed Hard-to-cook characteristic effect. All minerals studied showed a strong correlation with the cooking time. CNFC 10467 and Madrepérola varieties are more similar, as the parameters examined.
\end{abstract}

KEYWORDS: cooking time, the integument color, content of phytates.

\section{INTRODUCTION}

The bean (Phaseolus vulgaris L.) is one of the main sources of vegetable protein and minerals in the Brazilian population. It is present at the table of Brazilians, of all social classes and throughout the national territory. According to MAPA (2015), every ten Brazilians consume beans daily. There is a great variety of this legume, with different colors, shapes and sizes, allowing attending the habits of every country region.

Brazil is one of the world's largest bean producers, grown by small and large producers under diversified production systems in all regions of the country. Beans of the Phaseolus genus, known as common bean, are of great social and economic importance (SCHOENINGER et al., 2014a). It also exerts a social importance because of the large amount of labor involved in all phases of the culture. In recent years, they are using new technologies to facilitate and increase the production of this legume, such as irrigation and mechanized harvesting.

Brazil is the world's largest bean consumer and is in third place in the world rank of common bean production, behind Myanmar and India, the average world production in the period from 2007 to 2011 was 21.9 million tons (FAO, 2013). Only a small fraction of Brazilian bean production is exported, and in 2011, 4,400 tons of beans were exported. Among the main groups exported are pinto, black, cowpea or Vigna unguiculata and Frijol Canaval or sugar bean (BRASIL, 2015).

Bean grain quality can be determined mainly by acceptability, characteristics of cooking time, water absorption, color, as well as its nutritional characteristics (SCHOENINGER et al., 2013).The cooking time is a fundamental factor for the acceptance of a bean cultivar by consumers, since the availability for the preparation of meals is often restricted (OLIVEIRA et al., 2014).

Until arriving at the consumer's table, the beans inevitably pass through a period of storage. SOUZA et al. (2012) explain that the beans alter their color characteristics according to the storage period and initial conditions of cultivation. In Brazil, the storage of the bean grains, in most cases, is

\footnotetext{
${ }^{2}$ Western Paraná State University/ Cascavel - PR, Brasil.

${ }^{3}$ Federal University of Grande Dourados/ Dourados - MS, Brasil.

Received in: 4-8-2016

Accepted in: 12-5-2016
} 
done in uncontrolled conditions, in temperature and relative humidity conditions above the ideal. The way grains are stored influences the hardening of the tegument and the cotyledons and, consequently, the cooking time (OLIVEIRA et al. 2014).

The colored varieties, such as pinto beans, have teguments rich in anthocyanins and other phenolic compounds that give beans antioxidant properties (MCGEE, 2014), which is the case of phytic or phytate acid. The antinutritional factors present in beans, such as phytates, can affect the bioavailability of the minerals (BASSINELLO, 2014).

The consumers prefer the newly harvested beans, rejecting the aged product, for having a long cooking time and darkening of the tegument. Considering the above, the aim of this study was to evaluate the effects of beans storage on controlled temperature and humidity on the parameters of cooking time, tegument color, phytate content and mineral content ( $\mathrm{P}, \mathrm{Ca}, \mathrm{Mg}$ and $\mathrm{Mn}$ ).

\section{MATERIAL AND METHODS}

The experiment was carried out at the Laboratory of Control and Quality of Agricultural Products (LACON) of the State University of West Paraná (UNIOESTE) at Cascavel Campus in partnership with the Brazilian Agricultural Research Company - Rice and Beans (EMBRAPA), in Santo Antônio de Goiás - GO.

Bean grains (Phaseolus vulgaris L.) of the cultivars BRS Madrepérola, BRS Estilo, CNFC 10467 and BRS Pontal, cultivated in Santo Antônio de Goiás - GO from the 2013 harvest were used. The plots were harvested manually. The pods were threshed on a threshing machine and the beans were air dried naturally until reaching $13 \%$ of water content (h.b.). The storage condition occurred due to different associations of temperature and relative humidity, which represent the storage conditions of the bean grains in the different regions of Brazil (Table 1).

TABLE 1. Conditions of temperature, relative humidity and period that the grains were stored.

\begin{tabular}{cccc}
\hline Condition & $\begin{array}{c}\text { Storage } \\
\text { temperature }\left({ }^{\circ} \mathrm{C}\right)\end{array}$ & Relative Humidity (RH) & Storage time (days) \\
\hline Condition 1 & 15 & 45 & 36 \\
Condition 2 & 27 & 75 & 36 \\
Condition 3 & 21 & 60 & 72 \\
Condition 4 & 15 & 45 & 108 \\
Condition 5 & 27 & 75 & 108 \\
\hline
\end{tabular}

The grains were packed in hermetic acrylic containers with control of temperature and relative humidity. Twelve kilos of beans were used for each temperature range and relative humidity. Saturated saline solutions were used to achieve the desired moisture and to maintain them at the determined temperatures the containers were placed in air-conditioned chambers. The potassium carbonate salt $\left(\mathrm{K}_{2} \mathrm{CO}_{2}\right)$ was used to make the saturated salt solution for the combination of $15^{\circ} \mathrm{C}$ and $45 \%$ humidity, the saturated salt solution with the calcium nitrate salt $\left(\mathrm{Ca}\left(\mathrm{NO}_{3}\right)_{2}\right.$ was used for the combination of $21^{\circ} \mathrm{C}$ and $60 \%$ humidity, and the sodium chloride salt $(\mathrm{NaCl})$ was used for the combination of $27^{\circ} \mathrm{C}$ and $75 \%$ humidity. They were stored for 108 days under these conditions. After each storage period (36, 72 and 108 days), the whole bean grains of each cultivars were submitted to the analysis of cooking time, tegument color, phytate content and mineral content (P, $\mathrm{Ca}, \mathrm{Mg}$ and $\mathrm{Mn}$ ).

The color parameters were determined by direct reading of the bean grains with the Konica Minolta ${ }^{\circledR}$ colorimeter, CR410 model, with a $50 \mathrm{~mm}$ opening, which considers in its system the coordinates $\mathrm{L}^{*}, \mathrm{a}^{*}$ and $\mathrm{b}^{*}$, responsible for the luminosity, red content and yellow content, respectively. It also gives the values of $\mathrm{H}^{*}$ (Hue angle) and $\mathrm{C}^{*}$ (chromaticity index). The apparatus was initially calibrated on a white surface according to pre-established standards. The measurements in all samples were carried out with three replicates, obtaining average values of $\mathrm{L}^{*}$, $a^{*}, b^{*}, H^{*}$ and $C^{*}$ (GRANATTO \& MASSON, 2010). The parameter color difference in relation to 
the control $\left(\Delta \mathrm{E}^{*}\right)$, which was formed by freshly harvested grains and at zero storage time, was calculated by the following equation:

$$
\Delta E^{*}=\sqrt{\left(\Delta L^{*}\right)^{2}+\left(\Delta a^{*}\right)^{2}+\left(\Delta b^{*}\right)^{2}}
$$

that,

$\Delta \mathrm{E}^{*}$ - color difference in relation to the control;

$\Delta \mathrm{L}^{*}$ - difference between the luminosity of the sample and the control;

$\Delta \mathrm{a}^{*}$ - difference between the $\mathrm{a}^{*}$ component of the sample in relation to the control,

$\Delta \mathrm{b}^{*}$ - difference between the $\mathrm{b}^{*}$ component of the sample in relation to the control.

The cooking time was carried out by the method quoted by JACKSON \& VARIANOMATTSON (1981), using Mattson adapted equipment.

After each storage period, the raw bean grains of the studied cultivars were grounded in a knife mill to obtain the flour, which were sifted in a 50 mesh sieve, placed in polyethylene packages and stored at $-18^{\circ} \mathrm{C}$, until the analyzes.

For the determination of micronutrients and phosphorus $(\mathrm{P})$, the extract obtained from the samples through nitroperchloric digestion was used. $0.2 \mathrm{~g}$ of each flour sample was measured and added to the nitroperchloric solution in a 3:1 ratio (nitric acid + perchloric acid). This mixture was forwarded to the digester block for two hours at $180{ }^{\circ} \mathrm{C}$. The paper-digested contents were then filtered in 50-ml flasks completing with deionized water. For each sample, 3 replicates were made for the extract.

The analyzes of the $\mathrm{Ca}, \mathrm{Mg}$ and $\mathrm{Mn}$ mineral contents were carried out through atomic absorption spectrophotometry, according to the methodology proposed by (MALAVOLTA, 2006). The readings were adjusted by standard curve and the results were expressed in mg.kg- ${ }^{-1}$ The $P$ determination was carried out by colorimetry using the Flow Injection Analysis (FIA) apparatus in a spectrophotometer, FEMTO - 700 Plus model. The samples were read on the colorimetric spectrophotometer at $725 \mathrm{~nm}$ wavelength. The sample readings were adjusted by standard curve. The $\mathrm{P}$ results were expressed in $\mathrm{g} \cdot \mathrm{kg}^{-1}$.

Phytic acid analysis was carried out using the colorimetric method, using resin for DOWEX AGX - 4 (MARIOTTO-CEZAR et al., 2013).

Exploratory analysis of the data was carried out. Pearson's linear correlation analysis was applied to the variables of interest at the 5\% level of significance. The multivariate statistics analysis: principal components analysis (PCA) and cluster were applied to all response variables, using the statistically correlated and uncorrelated ( $p>0.05$ ). The analysis of PCA was used to interpret the relations between the evaluated parameters (cooking time, tegument color, phytate content and mineral content) of the cultivars. The main components were extracted from the correlation matrix of the original variables and considered sufficient the components that explained more than $70 \%$ of the data variance (MANLY, 2008). For the cluster analysis of the cultivars evaluated in this experiment, the procedure with hierarchical aggregation between the groups based on the Euclidean distance matrix was carried out.

\section{RESULTS AND DISCUSSION}

The luminosity (L) of the grains did not demonstrate significant changes during storage (Figure 1), and only in the condition 5, it was possible to observe reduction in luminosity in all varieties. The grains of the Madrepérola variety showed higher luminosity (67.05) at 36 days of storage, under conditions of $15^{\circ} \mathrm{C}$ and $45 \%$ of relative humidity. On the other hand, grains of BRS Pontal variety were the ones with the lower luminosity (53.61) when stored at $27^{\circ} \mathrm{C}$ and $75 \%$ of humidity at 108 days. 
SCHOENINGER et al. (2014a), when working with conventional and organic bean grains, found an average of grain luminosity of 52.39 and 52.11 for the conventional and organic grains, respectively.

The pinto beans studied in this study showed higher values of $\mathrm{L}^{*}$ than those found by the authors, so these grains are clearer and would therefore be better accepted by consumers.

The highest value found for chromaticity a* was in the BRS Estilo variety (9.12) at 36 of days storage under the conditions of $27{ }^{\circ} \mathrm{C}$ and $75 \%$ of relative humidity. The lowest value for chromaticity a* was at 36 days at $15^{\circ} \mathrm{C}$ and $45 \%$ of relative humidity in the BRS Madrepérola variety (3.93). The grains that showed the highest value for the chromaticity $b^{*}$ were those from the Madrepérola cultivar (15.65) at 36 days of storage, under the conditions of $27^{\circ} \mathrm{C}$ and $75 \%$ of relative humidity, the lowest (10.11) value of the grains of the BRS Pontal cultivar at 108 days of storage was under the conditions of $27^{\circ} \mathrm{C}$ and $75 \%$ of relative humidity.

LOPES (2011) when studied the pinto grains grown at the water season, obtained an average of 6.85 for the chromaticity value $a^{*}$ and 12.05 for chromaticity $b^{*}$. SILOCHI et al. (2016) in their research noticed a decrease in the variables $a^{*}$ and $b^{*}$ for all cultivars stored for 180 days, compared to those stored for 60, 90 and 135 days, and the BRS Pontal variety had a higher value of a*, 5.04, compared to the other varieties studied. The values for $a^{*}$ and $b^{*}$ found in this study were close to those by the authors.

For the chroma color parameter, the BRS Pontal variety was responsible for the higher and lower value found. At 72 days of storage and at $21^{\circ} \mathrm{C}$ and $60 \%$ of relative humidity, it showed the higher chroma value (17.20) and at 108 days of storage under the conditions of $27^{\circ} \mathrm{C}$ and $75 \%$ of relative humidity the lower value for the chroma parameter (13.15). According to GRANATTO \& MASSON (2010), the higher the $C^{*}$ value is the more noticeable the product will be to human vision.

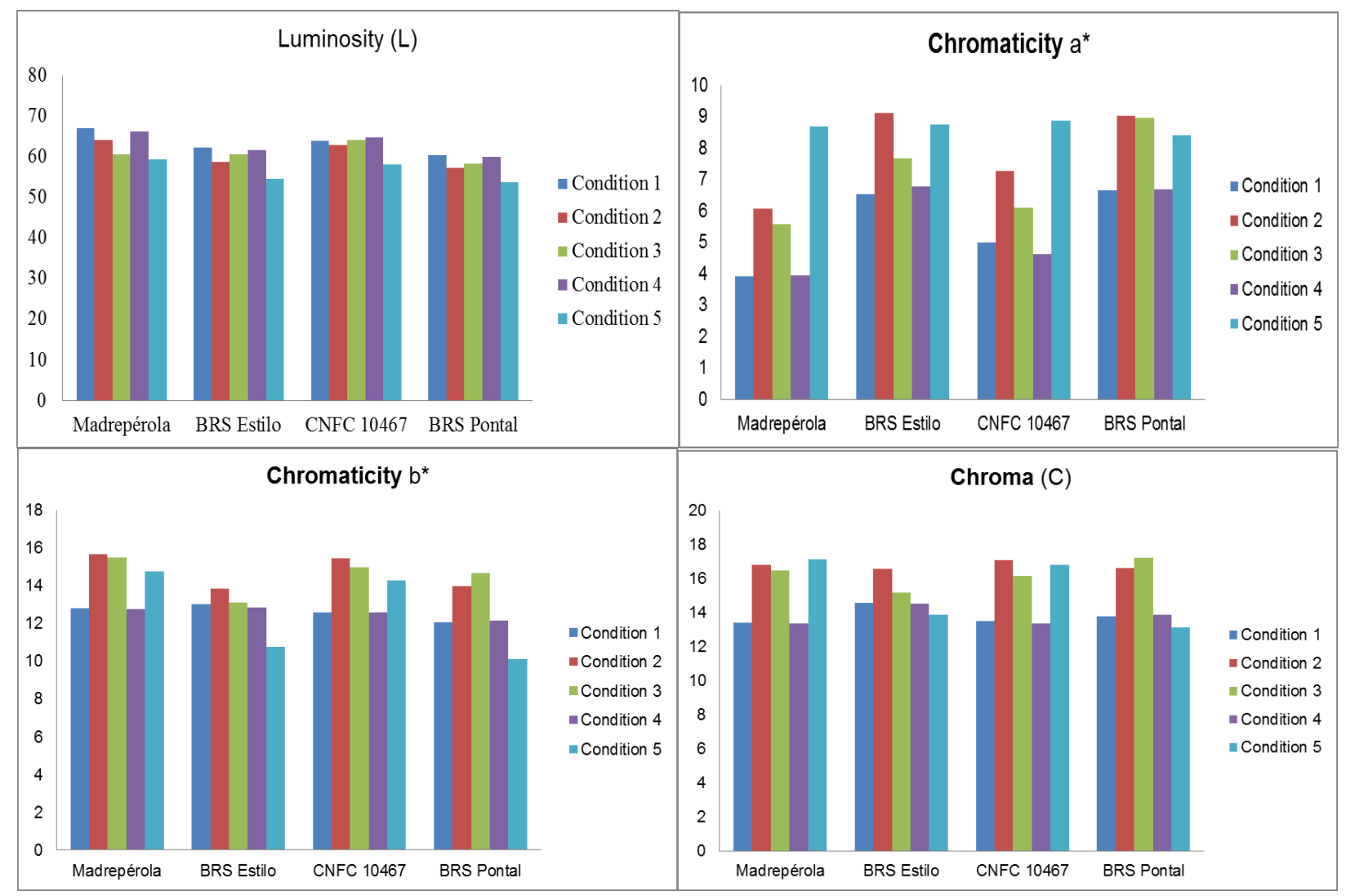




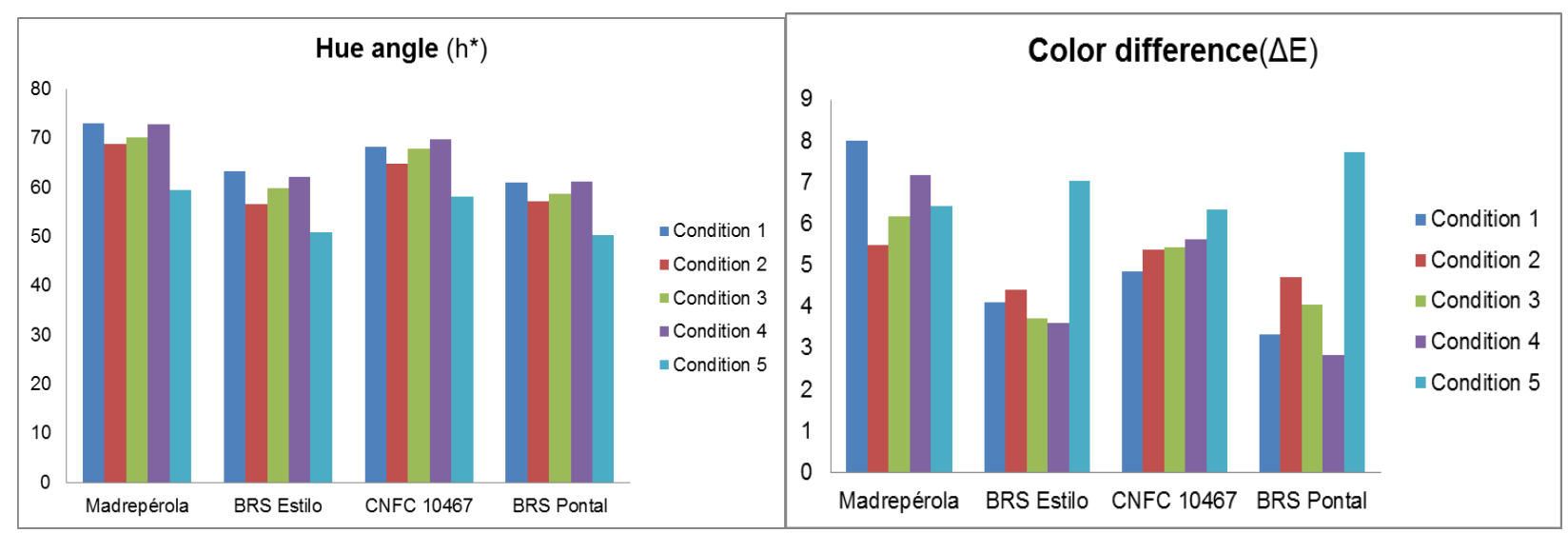

FIGURE 1. Averages for values of color parameters analysis for BRS Madrepérola, BRS Estilo, CNFC 10467 and BRS Pontal varieties during storage.

* Condition $1\left(15{ }^{\circ} \mathrm{C}, 15 \%\right.$ of $\mathrm{RH}$ and 36 days of storage), Condition $2\left(27^{\circ} \mathrm{C}, 75 \%\right.$ of $\mathrm{RH}$ and 36 days of storage), Condition $3\left(21^{\circ} \mathrm{C}, 60 \%\right.$ of $\mathrm{RH}$ and 72 days of storage) Condition $4\left(15^{\circ} \mathrm{C}, 45 \% \mathrm{RH}\right.$ and 108 days of storage) and Condition $5\left(27^{\circ} \mathrm{C}, 75 \%\right.$ of $\mathrm{RH}$ and 108 days of storage).

SCHOENINGER et al. (2014a) found values for the grains chromaticity of 15.18 for those from the conventional system and of 18.06 for the grains from the production in organic system, this parameter indicates the intensity of the grain color, the bigger its value is, the greater will be the perception of color for the human eye. Therefore, the grains with shorter storage period have a light brown coloration, which is desirable for consumers.

For the Hue angle ( $\left.\mathrm{h}^{*}\right)$, the BRS Madrepérola variety (72.92) was the best variety at 36 days of storage under the conditions of $15^{\circ} \mathrm{C}$ and $45 \%$ of relative humidity, an indicative of shade closer to the $90^{\circ}$ angle, with predominance of the yellow color, that is, grain with the lighter color shade. The lower value (50.24) presented for $\mathrm{h}^{*}$ was at 108 days of storage under the conditions of $27^{\circ} \mathrm{C}$ and $75 \%$ of relative humidity, an indicative of shade closer to the $45^{\circ}$ angle, predominantly red, or grains with a darker color. The highest color difference was observed at 36 days of storage in the BRS Madrepérola cultivar (8.02), under the conditions of $15^{\circ} \mathrm{C}$ and $45 \%$ of humidity, the values of the luminosity parameter $\left(\mathrm{L}^{*}\right)$ may have interfered with the value of the color difference because they were high. The lowest color difference (2.65) was at 108 days, in the BRS Pontal variety, under conditions of $15^{\circ} \mathrm{C}$ and $45 \%$ of humidity. According to SCHOENINGER et al. (2014b), when studying the color difference $(\Delta \mathrm{E})$ in beans of aged and pre-processed pinto group, we obtained results for this parameter between 2.24 and 14.54, so the values found in this study are among those found by the author. OOMAH et al. (2011), in a study with different bean genotypes, obtained for the color difference, values of $\Delta \mathrm{E}$ varying between 58.01 and 75.16 , therefore the values for this parameter found in these studies were not as relevant as those of the author. During storage, the compounds present in the seed tegument may undergo oxidation or other chemical changes leading to new compounds that change the grain color (MARTIN-CABREJAS et al., 1997).

The lowest cooking time (15.5 minutes) was observed in the grains of the BRS Estilo variety at 36 days of storage under conditions of $15^{\circ} \mathrm{C}$ and $45 \%$ of humidity (Figure 2). The highest cooking time (240.5 minutes) was observed in the BRS Pontal variety at 108 days storage, under the conditions of $27^{\circ} \mathrm{C}$ and $75 \%$ of humidity. SIQUEIRA et al. (2014) studied the cooking time of BRS Estilo, BRS Madreperola and BRS Pontal genotypes and recorded times of 18, 19 and 22 minutes, respectively. For the first storage periods, the cooking time values were similar to those found by the authors.

OLIVEIRA et al. (2011) when storing beans of the pinto group for a period of six months under refrigerated conditions, found that the cooking time increased in relation to the initial one for all varieties under study, and the Pérola variety showed the highest changes in cooking time (from 23.4 minutes to 30.4 minutes). The varieties of this study also showed an increase in the cooking time during the storage period, and those that were stored at lower temperatures had little variation 
in cooking time, while those that were stored at elevated temperatures showed greater changes in the cooking time.

COELHO et al. (2009), when working with new and aged black and pinto beans stored in natural conditions, verified an increase in cooking time in both types of beans after storage, due to the hard-to-cook effect. The grains that were stored longer (108 days) and in extreme temperature and humidity conditions $\left(27^{\circ} \mathrm{C}\right.$ and $75 \%$ of relative humidity) had a significant increase in cooking time in relation to the other storage conditions, indicating that the grains suffered the Hard-to-cook effect, in the same way that was found in the author's research. The Hard-to-cook effect, or also called hard-to-cook grains, occurs when there is impermeability and difficulty of softening of the grains, in consequence of the formation of metabolites such as quinone, through the action of catechol oxidase and diphenols, resulting in polyphenase activity (UEBERSAX \& SIDDIQ, 2013), due to inadequate storage.

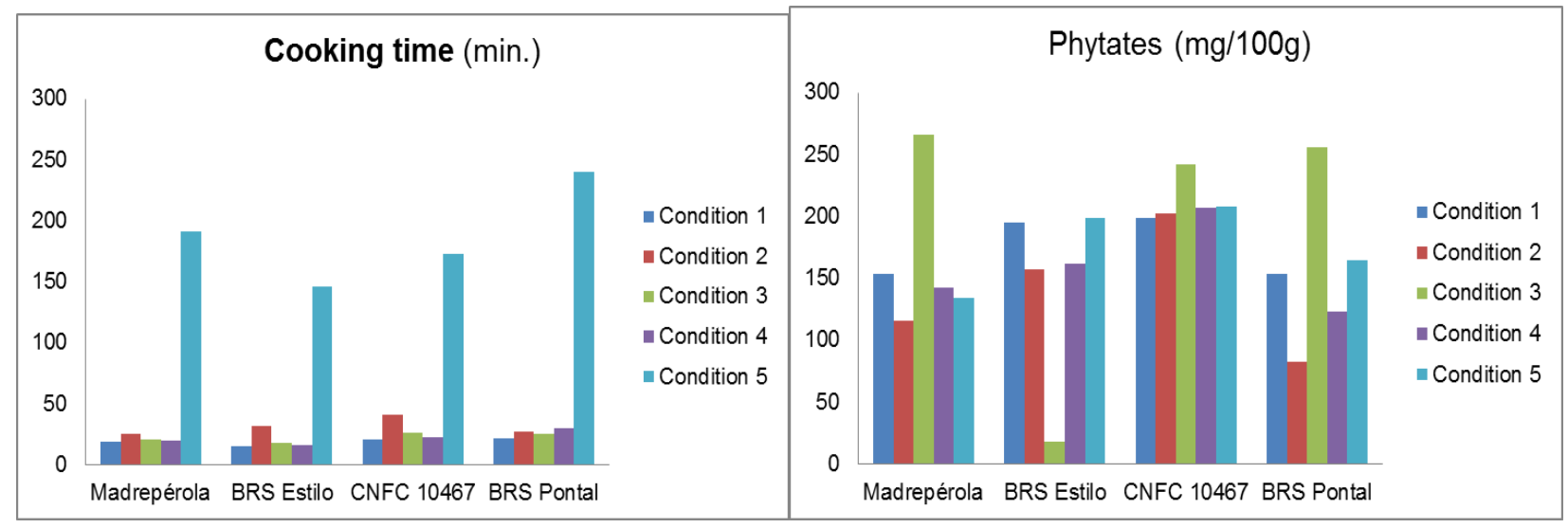

FIGURE 2. Averages for values of cooking time parameters and phytate content analysis of BRS Madrepérola, BRS Estilo, CNFC 10467 and BRS Pontal varieties during storage.

* Condition $1\left(15^{\circ} \mathrm{C}, 15 \%\right.$ of $\mathrm{RH}$ and 36 days of storage), Condition $2\left(27^{\circ} \mathrm{C}, 75 \%\right.$ of $\mathrm{RH}$ and 36 days of storage), Condition $3\left(21^{\circ} \mathrm{C}, 60 \%\right.$ of $\mathrm{RH}$ and 72 days of storage) Condition $4\left(15^{\circ} \mathrm{C}, 45 \% \mathrm{RH}\right.$ and 108 days of storage $)$ and Condition $5\left(27^{\circ} \mathrm{C}, 75 \%\right.$ of $\mathrm{RH}$ and 108 days of storage $)$.

The Madrepérola variety had the highest phytate content $\left(266.41 \mathrm{mg} .100 \mathrm{~g}\right.$ sample $\left.^{-1}\right)$ at 72 days of storage under the conditions of $21^{\circ} \mathrm{C}$ and $60 \%$ of humidity, whereas the variety with the lowest content of phytate $\left(18.35 \mathrm{mg} .100 \mathrm{~g}\right.$ sample $\left.^{-1}\right)$ was BRS Estilo also at 72 days of storage under the conditions of $21^{\circ} \mathrm{C}$ and $60 \%$ of humidity.

For the $\mathrm{P}$ values (Figure 3), the variety with the higher value $\left(6.84 \mathrm{~g}^{\mathrm{kg}} \mathrm{kg}^{-1}\right)$ was CNFC 10467 at 72 days of storage under conditions of $21^{\circ} \mathrm{C}$ and $60 \%$ of humidity, the BRS Pontal variety showed the lower value $\left(1.28 \mathrm{~g} \cdot \mathrm{kg}^{-1}\right)$ of $\mathrm{P}$ at 108 days of storage under conditions of $15^{\circ} \mathrm{C}$ and $45 \%$ of humidity. SILVA et al. (2013) when analyzing the mineral concentrations in raw and cooked grains of two varieties of beans: biofortified pinto (Pontal) and common pinto (commercial) purchased in the retail trade and analyzed, found for the crude treatment and P contents of 5.56 (Pontal) and $5.31 \mathrm{~g} . \mathrm{kg}^{-1}$ (Commercial). The values analyzed for the $\mathrm{P}$ content, in the four cultivars studied, were mostly below the values found by the authors. BURATTO (2012) found levels of P between 2.24 and $11.17 \mathrm{~g} . \mathrm{kg}^{-1}$, values within the range found in this study. 


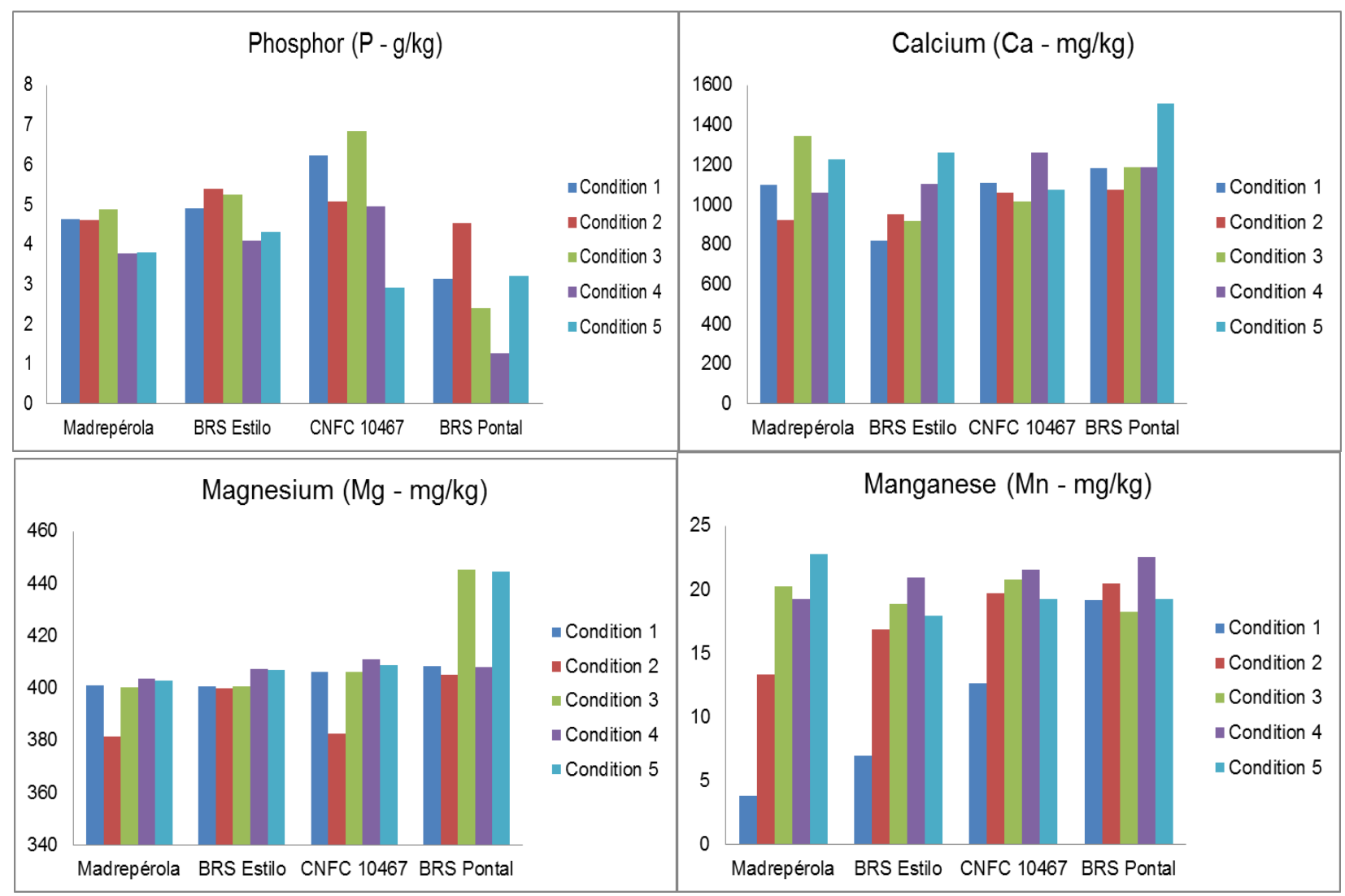

FIGURE 3. Averages for values of mineral parameters analysis for BRS Madrepérola, BRS Estilo, CNFC 10467 and BRS Pontal varieties during storage.

* Condition $1\left(15^{\circ} \mathrm{C}, 15 \%\right.$ of $\mathrm{RH}$ and 36 days of storage), Condition $2\left(27^{\circ} \mathrm{C}, 75 \%\right.$ of $\mathrm{RH}$ and 36 days of storage), Condition $3\left(21^{\circ} \mathrm{C}, 60 \%\right.$ of $\mathrm{RH}$ and 72 days of storage) Condition $4\left(15^{\circ} \mathrm{C}, 45 \% \mathrm{RH}\right.$ and 108 days of storage $)$ and Condition $5\left(27^{\circ} \mathrm{C}, 75 \%\right.$ of $\mathrm{RH}$ and 108 days of storage $)$.

The BRS Pontal variety showed higher Ca content $\left(1,506.43 \mathrm{mg} \cdot \mathrm{kg}^{-1}\right)$ for the grains stored for 108 days under the conditions of $27^{\circ} \mathrm{C}$ and $75 \%$ of humidity. The lowest Ca content $\left(818.03 \mathrm{mg} \cdot \mathrm{kg}^{-}\right.$ ${ }^{1}$ ) was observed in the BRS Estilo variety at 36 days of storage under the conditions of $15^{\circ} \mathrm{C}$ and $45 \%$ of humidity. SILVA et al. (2012), when quantifying protein and mineral levels in common bean lines, found, on average, the Ca content in pinto beans of $148 \mathrm{mg} . \mathrm{kg}^{-1}$. The Ca values found in the four bean varieties studied were higher than those found by the authors in all storage conditions.

The higher Mn content (22.79 mg. $\left.\mathrm{kg}^{-1}\right)$ was observed in the Madrepérola variety at 108 days of storage under conditions of $27^{\circ} \mathrm{C}$ and $75 \%$ of humidity. And the lower value $\left(3.80 \mathrm{mg} \cdot \mathrm{kg}^{-1}\right)$ was also observed in the same variety, but it was in the grains with 36 days of storage under conditions of $15^{\circ} \mathrm{C}$ and $45 \%$ of humidity. SILVA et al. (2013) found the average values of 17.18 and 17.70 mg. $\mathrm{kg}^{-1}$ of $\mathrm{Mn}$ content in bean grains (Pontal and commercial) analyzed crude and cooked, respectively, the values for the Mn content found in this study were similar to those found by the authors.

The higher $\mathrm{Mg}$ content (445.30 mg. $\mathrm{kg}^{-1}$ ) was observed in the BRS Estilo variety at 72 days of storage under conditions of $21^{\circ} \mathrm{C}$ and $60 \%$ of humidity. And the lower value for the $\mathrm{Mg}$ content (381.43 mg. $\mathrm{kg}^{-1}$ ) was also observed in the Madrepérola variety with 36 days of storage under conditions of $27^{\circ} \mathrm{C}$ and $75 \%$ of humidity.

Table 2 shows the Pearson's correlation matrix for the technological and chemical variables studied for the four varieties of pinto beans. It is possible to identify that the color parameters evaluated of the pinto bean varieties had a significant correlation, which happened because the Hue angle is derived from $\mathrm{L}^{*}, \mathrm{a}^{*}$ and $\mathrm{b}^{*}$ components, and the color difference originates from an equation that uses the same components. And the chroma indicates the intensities of these components. 
TABLE 2. Estimates of Pearson's correlations between technological and chemical quality variables of common bean.

\begin{tabular}{|c|c|c|c|c|c|c|c|c|c|c|c|c|}
\hline & $\mathrm{L}^{*}$ & $\mathrm{a}^{*}$ & $\mathrm{~b}^{*}$ & $\mathrm{C}$ & $\mathrm{h}^{*}$ & $\Delta \mathrm{E}$ & CT & Phytates & $\mathrm{P}$ & $\mathrm{Ca}$ & $\mathrm{Mn}$ & $\mathrm{Mg}$ \\
\hline $\mathrm{L}^{*}$ & - & & & & & & & & & & & \\
\hline$a^{*}$ & -0.970 & - & & & & & & & & & & \\
\hline $\mathrm{b}^{*}$ & 0.955 & -0.988 & - & & & & & & & & & \\
\hline $\mathrm{C}$ & 0.971 & -0.972 & 0.990 & - & & & & & & & & \\
\hline$h^{*}$ & 0.975 & -0.999 & 0.992 & 0.981 & - & & & & & & & \\
\hline$\Delta \mathrm{E}$ & 0.910 & -0.978 & 0.949 & 0.906 & 0.969 & - & & & & & & \\
\hline CT & -0.337 & 0.157 & -0.049 & -0.112 & -0.156 & -0.119 & - & & & & & \\
\hline Phytates & 0.568 & -0.491 & 0.598 & 0.680 & 0.526 & 0.315 & 0.133 & - & & & & \\
\hline $\mathrm{P}$ & 0.666 & -0.464 & 0.438 & 0.543 & 0.486 & 0.322 & -0.777 & 0.520 & - & & & \\
\hline $\mathrm{Ca}$ & -0.255 & 0.046 & 0.043 & -0.042 & -0.052 & 0.024 & 0.979 & 0.044 & -0.812 & - & & \\
\hline $\mathrm{Mn}$ & -0.493 & 0.441 & -0.303 & -0.286 & -0.420 & -0.504 & 0.816 & 0.354 & -0.489 & 0.682 & - & \\
\hline $\mathrm{Mg}$ & -0.842 & 0.732 & -0.653 & -0.689 & -0.732 & -0.687 & 0.787 & -0.236 & -0.839 & 0.708 & 0.825 & - \\
\hline
\end{tabular}

*They were statistically significant at the $5 \%$ probability level through t Test.

The cooking time (CT) showed a positive correlation with the calcium content $(\mathrm{Ca})(\mathrm{r}=$ $0.979, \mathrm{p}<0.05)$, but it was also possible to observe other correlations of the cooking time with other minerals, which were not significant at $5 \%$ level but they were considered as strong (above 0.70), with $\mathrm{Mg}$ content $(\mathrm{r}=0.787)$, Mn content $(\mathrm{r}=0.816)$, and $\mathrm{P}$ content $(\mathrm{r}=-0.777)$.

The magnesium content parameter $(\mathrm{Mg})$ showed strong correlation with the parameters $\mathrm{L}^{*}(\mathrm{r}$ $=-0.842), \mathrm{h}^{*}(\mathrm{r}=-0.732), \mathrm{Ca}(\mathrm{r}=0.708, \mathrm{p}>0.05)$ and $\mathrm{Mn}(\mathrm{r}=0.825, \mathrm{P}>0.05)$, even though these correlations were not significant at the $5 \%$ level of significance.

Figure 4 shows the two main components of the data, from the analysis generated from the 12 original dependent variables. The components F1 and F2 showed $89.45 \%$ of explanation for the variance of the parameters results evaluated in the four varieties of pinto beans grains.

In Biplot (Figure 4), the variation and the association between the technological and chemical parameters, as well as the relative performance of the cultivars for each one of the parameters evaluated, are verified. For the main component $(\mathrm{F} 1)$, there was a greater contribution of only two chromaticity variables $\mathrm{a}^{*}$ and $\mathrm{P}$ content. For the $\mathrm{F} 2$ component ocurred the highest contribution of the variables: manganese $(\mathrm{Mn})$, magnesium $(\mathrm{Mg})$, calcium $(\mathrm{Ca})$, phytate content, color parameters $\left(\mathrm{L}^{*}, \mathrm{~b}^{*}, \mathrm{~h}^{*}\right.$ and color difference) and cooking time. The Biplot showed three cultivars positively positioned for F2, with BRS Madrepérola and CNFC 10467 in the same quadrant, differentiating only the BRS Pontal, because it is in the upper and lower quadrant and showed higher values for the manganese, magnesium, calcium and cooking time. Only the BRS Estilo variety remained in the lower left quadrant, since they showed higher values for the chromaticide variable $\mathrm{a}^{*}$. 


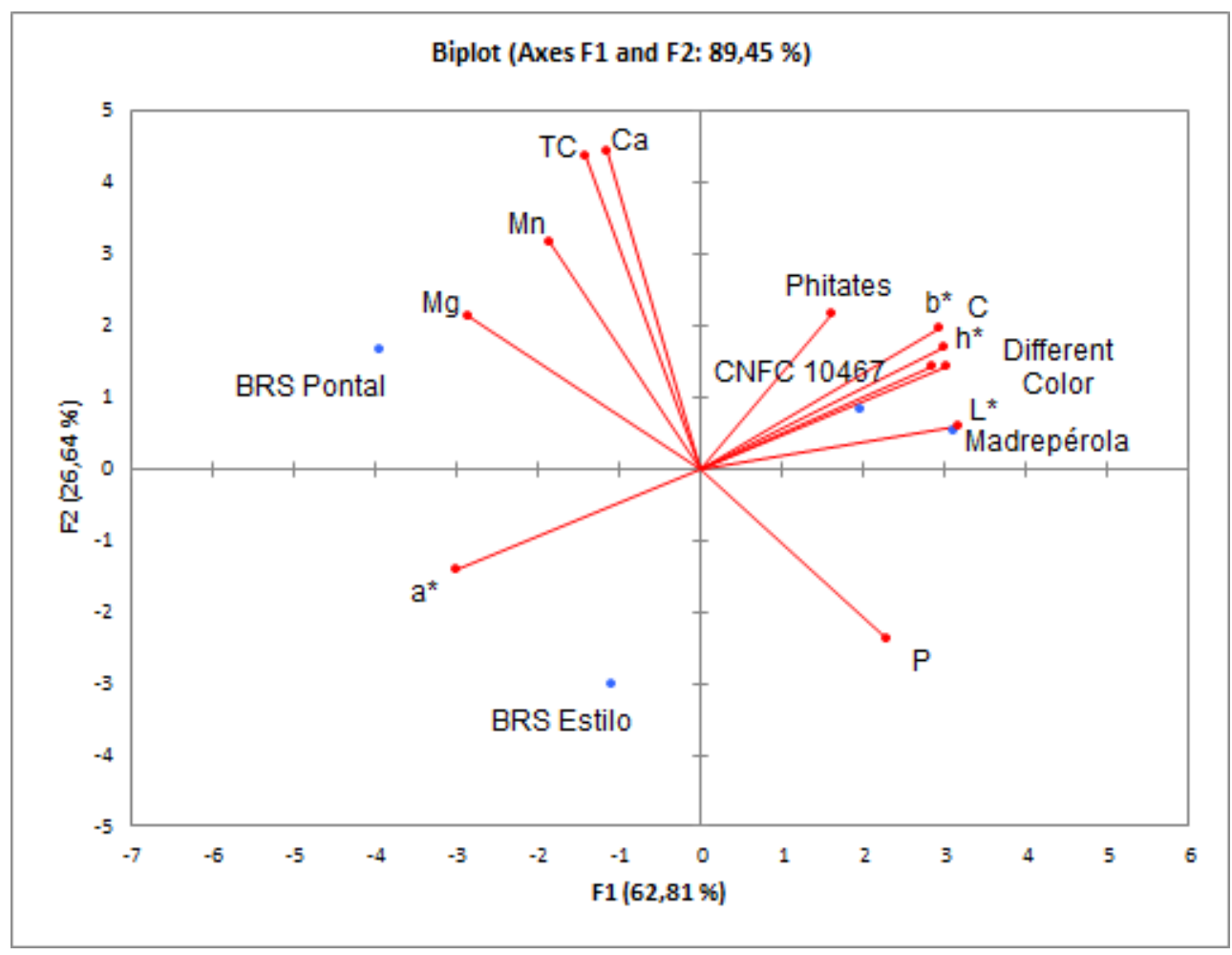

FIGURE 4. Biplot resulting from the principal component analysis for the 4 varieties of common bean and 12 dependent variables studied.

Figure 5 shows the graphical result of hierarchical agglomerative cluster analysis for the evaluated bean cultivars.

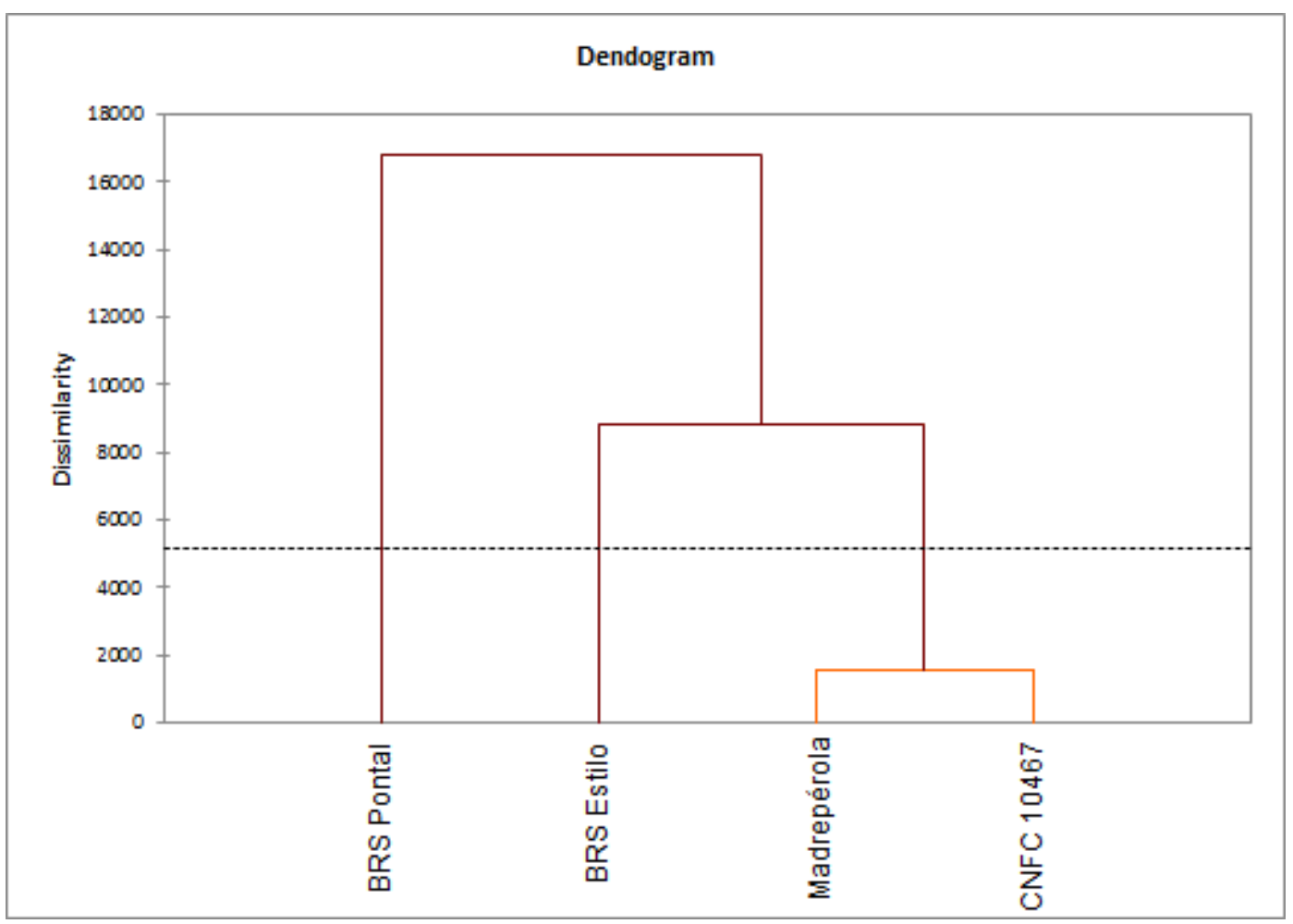

FIGURE 5. Dendrogram resulting from hierarchical agglomerative cluster analysis for four common bean cultivars (BRS Madrepérola, BRS Estilo, CNFC 10467 and BRS Pontal).

The cluster analysis (Figure 5) showed a separation of two distinct groups. The first cluster is formed by the cultivar BRS Pontal. The second one is formed by BRS Estilo, CNFC 10467 and BRS Madrepérola cultivars, the last two being more similar when compared to the first. The BRS 
Madrepérola and CNFC 10467 varieties had similar values of phytate content, chromaticity b*, chroma, hue angle, color difference and luminosity (Figure 4), corroborating with the cluster analysis.

\section{CONCLUSIONS}

All varieties had better results in the studied parameters when stored at $15^{\circ} \mathrm{C}$ and $45 \%$ of $\mathrm{RH}$. The Madrepérola variety was superior in relation to the luminosity color parameter when comparing the other varieties studied. The storage condition and storage time influence the increase in cooking time. The grains stored at $27^{\circ} \mathrm{C}$ and $75 \%$ of humidity at 108 , showed a Hard-to-Cook effect. All minerals studied showed a strong correlation with cooking time. The BRS Pontal variety was the one that most differed from the other varieties studied. The CNFC 10467 and Madrepérola varieties are more similar, regarding the parameters studied.

\section{REFERENCES}

BASSINELLO, P. Z. Pós-produção: Qualidade dos grãos. 2014. Santo Antonio de Goiás: Embrapa Arroz e Feijão. Disponível em:

<http://www.agencia.cnptia.embrapa.br/Agencia4/AG01/arvore/AG01_2_28102004161635.html>. Acesso em: 30 jan. 2016.

BRASIL. Ministério da Agricultura Pecuária e Abastecimento. Perfil do feijão no Brasil. 2015. Disponível em: <http://www.agricultura.gov.br/vegetal/culturas/feijao/saiba-mais>. Acesso em: 15 mar. 2015.

\section{BURATTO, J. S. Teores de minerais e proteínas em grãos de feijão e estimativas de} parâmetros genéticos. 2012. 148 f. Tese (Doutorado em Genética e Melhoramento de Plantas) Universidade Federal de Lavras, Lavras, 2012.

COELHO, S.R.M.; PRUDENCIO, S.N.; NOBREGA, L.H.P.; LEITE, C.F.R. Alterações no tempo de cozimento e textura dos grãos de feijão comum durante o armazenamento. Ciência e Agrotecnologia, Lavras, v. 33, n. 2, p. 539-544, 2009. Disponível em: <http://www.scielo.br/scielo.php?script=sci_arttext\&pid=S1413-70542009000200028>. Acesso em: 15 mar. 2015.

FAO - FOOD AND AGRICULTURE ORGANIZATION OF THE UNITED NATIONS. Fao stat. 2013. In: PARANÁ. Secretaria de Estado da Agricultura e do Abastecimento - SEAB.

Departamento de Economia Rural - DERAL. Feijão: análise da conjuntura agropecuária - 2013. Disponível em:

http://www.agricultura.pr.gov.br/arquivos/File/deral/Prognosticos/feijao_2013_14.pdf. Acesso em: 20 dez. 2014.

GRANATTO, D.; MASSON, M. L. Instrumental color and sensory acceptance of soy-based emulsions: a response surface approach. Ciência e Tecnologia de Alimentos, Campinas, v. 30, n. 4, p. 1090-1096, out./dez, 2010.

JACKSON, M. G.; VARRIANO-MARSTON, E. Hard-to-cook phenomenon in beans: effects of accelerated storage on water absorption and cooking time. Journal of Food Science, Chicago, v. 46, p. 799-803, 1981.

LOPES, R. L. T. Características tecnológicas de genótipos de feijoeiro em razão de épocas de cultivo e períodos de armazenamento. 2011. 77 f. Dissertação (Mestrado em Agricultura Tropical e Subtropical) - Instituto Agronômico, IAC, Campinas, 2011.

MALAVOLTA, E. Manual de nutrição mineral de plantas. São Paulo: Agronômica Ceres, 2006. $631 \mathrm{p}$.

MANLY, B. J. F. Métodos estatísticos multivariados: uma introdução. Tradução Carmona, SIC. Porto Alegre: Bookman, 2008. 
MAPA. Perfil do feijão no Brasil. 2015. Disponível em:

<http://www.agricultura.gov.br/vegetal/culturas/feijao/saiba-mais>. Acesso em: 15 mar. 2015.

MARIOTTO-CEZAR, T.; COELHO, S. R. M.; CHRIST, C.; SCHOENINGER, V.; ALMEIDA, A. J. B. Nutritional and antinutritional factors during the storage process of common bean.

International Journal of Food, Agriculture and Environment, Helsinki, v. 11, p. 268-272, 2013. Disponível em:

$<$ https://www.researchgate.net/publication/264704982_Nutritional_and_antinutritional_factors_duri ng_the_storage_process_of_common_bean>. Acesso em: 15 mar. 2015.

MARTIN-CABREJAS, M. A.; ESTEBAN, R. M.; PEREZ, P.; MAINA, G.; WALDRON, K. W. Changes in physicochemical properties of dry beans (Phaseolus vulgaris L.) during long-term storage. Journal Agriculture and Food Chemistry, Washington, v. 45, p. 3223-3227, 1997.

MCGEE, H. Comida e cozinha: ciência e cultura da culinária. Tradução Marcelo Brandão Cipolla. São Paulo: Editora WMF; Martins Fontes. 2014. p. 977.

OLIVEIRA, D.M.; BISCHOFF, T.Z. SILOCHI, R.M.Q.; SCHOENINGER, V. COELHO, S.R.M. Considerações acerca da produção e qualidade de grãos de feijão. Journal of Agronomic Sciences, Umuarama, v.3, p.16-22, 2014. Número especial.

OLIVEIRA, V. R.; RIBEIRO, N. D.; MAZIERO, S. M.; CARGNELUTTI FILHO, A.; JOST, E. Qualidade para o cozimento e composição nutricional de genótipos de feijão com e sem armazenamento sob refrigeração. Ciência Rural. Santa Maria, v. 41, n. 5, p. 746-752, maio. 2011.

OOMAH, D. B.; LUC, G.; LEPRELLE, C.; DROVER, J. C. G.; HARRISON, J. E.; OLSON, M. Phenolics, phytic acid, and phytase in Canadian-grown low-tannin faba bean (Vicia faba L.) genotypes. Journal of Agricultural and Food Chemistry, Washington, v. 59, p. 3763-3771, 2011. SCHOENINGER, V.; SILOCHI, R.M.H.Q.; TONINI, M; BATISTA, V.T.; LORIN, H.E.F. Caracterização de atributos tecnológicos e de cor em grãos de feijão produzidos em diferentes sistemas: orgânico e convencional. Cultivando o Saber, Cascavel, v.7, n.3, p. 212-220, 2014a.

SCHOENINGER, V.; COELHO, S. R. M.; CHRIST, D.; SAMPAIO, S. C. Processing parameter optimization for obtaining dry beans with reduced cooking time. Food Science and Technology, Heidelberg, v. 56, p. 49-57, 2014b.

SCHOENINGER, V.; COELHO, S.R.M.; CHRIST, D.; SAMPAIO, S.C.; ALMEIDA, A.J.B. Preprocessing of aged carioca beans: Soaking effect in sodium salts in the cooking and nutrition quality. Journal of Food, Agriculture \& Environment, Helsinki, v. 11, n. 1, p. 184-189, set/jan, 2013.

SILOCHI, R.M.H.Q.; COELHO, S.R.M.; BISCHOFF, T.Z.; CASSOL, F.D.R.; PRADO, N.V.; BASSINELLO, P.Z. Nutritional technological characterization and secondary metabolites in stored carioca bean cultivars. African Journal of Agricultural Research, Nigéria, v. 11, n. 24, p. 21022111, mar./mai. 2016.

SILVA, C.A.; ABREU,A.F.B.; RAMALHO, M.A.P.; MAIA, L.G.S. Chemical composition as related to seed color of common bean. Crop Breeding and Applied Biotechnology, Londrina, v. 12, p. 132-137, 2012.

SILVA, M. O.; BRIGIDE, P.; CANNIATTI-BRAZACA, S. G. Caracterização da composição centesimal e mineral de diferentes cultivares de feijão comum crus e cozidos. Alimentação e Nutrição. Brazil Journal Food Nutrition, Araraquara, v. 24, n. 3, p. 339-346, jul./set. 2013.

SIQUEIRA, B. S.; PEREIRA, W. J.; BATISTA, K. A.; OOMAH, D. B.; FERNANDES, K. F.; BASSINELLO, P. Z. Influence of storage on darkening and hardening of slow - and regular carioca bean (Phaseolus vulgaris 1.) genotypes. Journal of Agricultural Studies, Cambridge, v. 2, n. 2, p. 2166-0369, 2014. 
SOUZA, B. P.; GIORA, F. C.; PERINA, E. F.; LOPES, R. L. T.; CARVALHO, C. R. L.;

CARBONELL, S. A. M. Determinação da composição da parede celular e suas implicações no tempo de cozimento de grãos de feijão ( $\mathrm{N}^{\circ}$ 12118) In: CONGRESSO INTERINSTITUCIONAL DE INICIAÇÃO CIENTÍFICA, 2012, São Paulo. Anais... Jaguariúna: CIIC, 2012.

UEBERSAX, M.A.; SIDDIQ, M. Market classes and Physical and Physiological characteristics of dry beans. In: SIDDIQ, M.; UEBERSAX, M.A. Dry beans and pulses: production, processing and nutrition. Ames: Jonh Wiley \& Sons, 2013. p. $55-74$. 